\title{
The Oportunidades Conditional Cash Transfer Program: Effects on Pregnancy and Contraceptive Use Among Young Rural Women in Mexico
}

\begin{abstract}
CONTEXT: Oportunidades is a large conditional cash transfer program in Mexico. It is important to examine whether the program has any direct effect on pregnancy experience and contraceptive use among young rural women, apart from those through education.
\end{abstract}

METHODS: Data from the 1992, 2006 and 2009 waves of a nationally representative, population-based survey were used to describe trends in pregnancy experience, contraceptive use and education among rural adolescent (15-19) and young adult (20-24) women in Mexico. To examine differences in pregnancy experience and current modern contraceptive use among young women, multivariable logistic regression analyses were conducted between matched 2006 samples of women with and without exposure to Oportunidades, predicted probabilities were calculated and indirect effects were estimated.

RESULTS: Over the three survey waves, the proportion of adolescent and young adult women reporting ever being pregnant stayed flat (33-36\%) and contraceptive use increased steadily (from 13\% in 1992 to 19\% in 2009). Educational attainment rose dramatically: The proportion of women with a secondary education increased from $28 \%$ in 1992 to 46\% in 2009. In multivariable analyses, exposure to Oportunidades was not associated with pregnancy experience among adolescents. Educational attainment, marital status, pregnancy experience and access to health insurance-but not exposure to Oportunidades - were positively associated with current modern contraceptive use among adolescent and young adult women.

CONCLUSION: Through its effect on education, Oportunidades indirectly influences fertility among adolescents. It is important for Mexico to focus on strategies to increase contraceptive use among young rural nulliparous women, regardless of whether they are enrolled in Oportunidades.

International Perspectives on Sexual and Reproductive Health, 2013, 39(4):205-214, doi: 10.1363/3920513

Much of Latin America has experienced steep declines in fertility over the past three decades: The mean total fertility rate for the region dropped from 5.1 children in the mid1970s to 2.5 children in $2005 .^{1}$ Mexico, which has had an explicit population policy since the 1970s, has followed this trend. ${ }^{2}$ Despite progress at the national level, disparities persist in Mexico, with poor, rural and indigenous women having lower contraceptive use rates and higher fertility rates than do more affluent, urban and nonindigenous women, respectively. ${ }^{3}$ Furthermore, adolescent fertility has not declined at the same pace as overall fertility. Age-specific fertility rates indicate that the contribution to total fertility by women aged 15-19 has risen in some Latin American countries, with a disproportionately high burden of early fertility among rural adolescents. ${ }^{4}$ Early pregnancy is associated with adverse health outcomes for women and children, ${ }^{5}$ increased total fertility ${ }^{6}$ and poverty. ${ }^{7}$ Reducing unintended early fertility is a key strategy to decrease poverty and improve women's health.

One approach to poverty reduction is through conditional cash transfer programs, ${ }^{8}$ which are a form of performance-based payment-generally targeted toward poor households or individuals-in exchange for compli- ance with a set of behavioral requirements or conditionalities, such as school attendance or health service utilization. ${ }^{9}$ Conditional cash transfer programs have been implemented in several countries in Latin America and Sub-Saharan Africa, as well as in India, Bangladesh, Nepal and the United States, ${ }^{10-16}$ and have been shown to increase utilization of conditionalities, ${ }^{8,17,18}$ however, evidence about programs' effects on short- and long-term health outcomes has been mixed. ${ }^{9,18,19}$ Programs vary widely in structure, ${ }^{9}$ and it is not clear which program structures, conditionalities or components are most influential, although studies comparing conditional and unconditional cash transfers ${ }^{20}$ suggest that incentives are more effective with short-term behavior changes than with longer-term outcomes. ${ }^{21}$ The causal pathway for observed effects of conditional cash transfer programs is not fully understood. ${ }^{17}$

\section{Mexico's Oportunidades Program}

The conditional cash transfer program Oportunidadesestablished by the Mexican government in 1997 as PROGRESA-is the largest of its kind, ${ }^{22}$ and aims to reduce poverty and develop human capital in poor households via improvements in child nutrition, health and education. 23,24
By Blair G. Darney, Marcia R. Weaver, Sandra G. SosaRubi, Dilys Walker, Edson ServanMori, Sarah Prager and Emmanuela Gakidou

Blair G. Darney, at the time of this analysis, was a doctoral student in the Department of Health Services, School of Public Health, University of Washington, Seattle, USA. Marcia $R$. Weaver is research associate professor, Emmanuela Gakidou is professor and Dilys Walker is associate professor-all with Department of Global Health, University of Washington. Sarah Prager is associate professor, Department of Obstetrics and Gynecology, University of Washington. Sandra G. Sosa-Rubi is investigator and Edson Servan-Mori is analyst-both with Instituto Nacional de Salud Publica, Cuernavaca, Mexico. 
The program provides money to female household heads or wives of household heads contingent on household compliance with gender- and age-specific health service utilization requirements, such as prenatal, postpartum and pediatric visits, as well as nutritional supplementation and school attendance. ${ }^{* 24,25}$ Transfer amount is linked to household demographic structure, but equals approximately $20 \%$ of the family's preprogram monthly expenditures. ${ }^{26}$ In 2006, Oportunidades covered five million families in the 32 Mexican states-86\% of whom resided in rural areas; ${ }^{27}$ in 2012, the program covered 5.8 million families, which means that about $20 \%$ of Mexicans were beneficiaries. ${ }^{28}$ Oportunidades has the largest budget of any federal human development program in Mexico. ${ }^{29}$ Details of Oportunidades, the cash transfer ${ }^{30}$ and results from the early experimental phase of the program ${ }^{\dagger}$ have been published elsewhere. $^{22,25}$

Oportunidades' design reflects a belief that a comprehensive approach to building human capital by investing in mothers and children may reap broad social returns, ${ }^{29,30}$ including positive changes in fertility behaviors and outcomes. ${ }^{11}$ Oportunidades could affect fertility behavior through several mechanisms, including increased education. ${ }^{17,22}$ Women's education has been associated with fertility in analyses controlling for husband's education and other markers of socioeconomic status. ${ }^{31-34}$

Bongaarts hypothesized that education influences fertility through several proximate determinants: ${ }^{35}$ age at marriage, postnatal fecundity (via breast-feeding and postnatal abstinence practices) and contraceptive use..$^{31,34,36-39}$ The pathway from education to the proximate determinants of fertility, however, is not well understood. Education may operate at the cognitive level by imparting information, but the content of education may not be as important as the socialization associated with formal education. ${ }^{32,38,40}$ For example, formal education contains elements of Western culture (in the form of modern institutions, such as schools) and ways of knowing (such as enumeration and the written word). ${ }^{31}$ Oportunidades explicitly encourages female children to remain in school, by providing a larger transfer for girls than for boys, and for children in secondary school than for those in primary school. ${ }^{25}$ The program has increased educational achievement, ${ }^{41}$ and has been more successful in doing so among girls and indigenous children than among boys and nonindigenous children, respectively. ${ }^{42}$

In addition to the potential impact of the educational component of Oportunidades on fertility, the program may have benefits beyond formal education, and there

*The Oportunidades program requires pregnant women to receive five
prenatal check-ups and nutritional supplementation; postpartum wom-
en to receive two check-ups (at seven and 28 days postpartum) and
nutritional supplementation; and children and adolescents between
the ages of 2 and 19 to receive a pediatric check-up every six months.
In addition, adolescents and adults between the ages of 18 and 49 are
required to receive community-based training on health lifestyles and
cervical cancer screening.
tFrom 1998 to 2000 Oportunidades-then known as PROGRESA-was

†From 1998 to 2000, Oportunidades-then known as PROGRESA-w implemented in a cluster randomized design, prior to full scale-up. is policy support for the belief that such benefits may "trickle down" within households. ${ }^{29}$ Oportunidades stipulates that adolescents, as well as adults, receive medical check-ups every six months, although the administrative burden of monitoring compliance means that payment is not conditional on doing so. Such visits are opportunities to discuss reproductive health and learn about contraceptives, although the content of these visits across communities is not well documented. ${ }^{30}$ Improved access to health care and increased knowledge about contraception may reduce adolescent pregnancy and increase contraceptive use among young women. ${ }^{43}$

Research on reproductive behaviors and outcomes associated with exposure to Oportunidades has focused on improvements in antenatal care, ${ }^{25,27,44}$ skilled birth attendance ${ }^{45}$ and cesarean delivery rates. ${ }^{46}$ Beneficiaries appear to receive a better quality of prenatal care (measured by receipt of specific recommended prenatal services, including contraceptive counseling), ${ }^{44}$ although disparities in access to prenatal care ${ }^{47}$ and in skilled birth attendance ${ }^{45}$ exist by urban-rural location and by indigenous ethnicity. ${ }^{47}$

In studies of data from Oportunidades' experimental period, contraceptive use was higher among female heads of household exposed to the program than among their unexposed counterparts, ${ }^{1,11}$ with greater change among the poorest women than among wealthier women; ${ }^{48}$ no link was found between birth spacing and program exposure between 1998 and 2003. ${ }^{1}$ One study reported a negative impact on pregnancy and childbirth among women younger than 20 during the short-term follow-up experimental period (1998-2000), although the finding was nonsignificant after controlling for education. ${ }^{11}$ Among urban Oportunidades beneficiaries seeking prenatal care in 2003-2004, receipt of family planning counseling during antenatal care was associated with increased use of postpartum contraceptives. ${ }^{49}$

Oportunidades and other conditional cash transfer programs may have unintended consequences. ${ }^{11}$ One concern has been the potential for increased fertility among beneficiary families through, for example, higher payments for larger families ${ }^{3}$ or through a reduction in male migration, ${ }^{22}$ although there is no evidence of higher fertility among beneficiaries. ${ }^{11,30}$

The reproductive behavior of young women exposed to Oportunidades in childhood has implications for intergenerational transmission of poverty. Delaying childbearing is key to improving educational and health outcomes for young women, which in turn are linked to their prospects for escaping the cycle of poverty. ${ }^{43}$ The positive relationship between adolescent fertility, total fertility and poverty means that early pregnancy and adolescent contraceptive use are important outcomes in the context of Oportunidades. Investment in antenatal, infant and child health services may not result in decreased poverty if early fertility is not addressed. Oportunidades is an established program that links the rural poor to health services and has the potential to expand access to pregnancy prevention for 
adolescents; however, no studies to date have examined reproductive outcomes among young women in households participating in the program.

In much of the research after Oportunidades' experimental period, researchers have focused exclusively on female heads of household of reproductive age (15-49) and have relied on Oportunidades program data, without appropriate comparison groups. For this analysis, however, we used population-based data from women (heads of household and not) aged 15-24 exposed to Oportunidades and a matched comparison sample to examine the direct effect of the program on pregnancy and contraceptive use, in addition to any effect of education. Our study focuses on rural women, because the vast majority of Oportunidades beneficiaries live in rural areas, and large disparities exist between rural and urban women.

\section{METHODS}

\section{Data}

Data were drawn from the 1992, 2006 and 2009 waves of the Encuesta Nacional de la Dinámica Demográfica (ENADID), a nationally representative survey fielded by Mexico's Instituto Nacional de Estadística y Geografíais that uses a two-stage stratified probability sample from Mexico's 31 states and its federal district of Mexico City. ${ }^{50}$ Each wave includes survey modules covering household composition and characteristics, and demographic, education and health information on all household members. In addition, each wave includes a reproductive health module to be completed by each woman aged 15-54 residing in the household. Data are therefore a combination of household and individual-level information.

We selected the 1992 wave ( $\mathrm{N}=277,552$ ) because it provides data prior to implementation of Oportunidades. The 2006 survey ( $N=142,961$ ) was selected because it contains data about exposure to Oportunidades. We used the 2009 wave $(\mathrm{N}=343,887)$ because it is the most recent demographic survey; however, it does not contain an Oportunidades exposure variable. The ENADID was also fielded in 1997, but we were unable to use that wave because of poor data quality for the variables of interest.

We used data from the 2006 wave to examine associations between pregnancy and contraceptive use among rural young and adolescent women by exposure to the Oportunidades program. Data from all three waves were used to examine secular trends in outcomes and to provide context for cross-sectional multivariable analyses.

\section{Measures}

- Dependent variables. We examined two outcome measures: lifetime experience of a pregnancy and current use of a contraceptive method. At each wave, women aged 15-54 were asked if they had ever been pregnant and if they were currently pregnant. Our pregnancy measure included both of these items to capture women's previous and current pregnancies. In addition, women aged 15-54 were asked about their knowledge of a list of contracep- tive methods, and about their ever-use of methods about which they reported having knowledge. Those who reported ever having used a method were asked whether they were currently using a method. Methods included male and female sterilization and "natural" methods, as well as barrier, hormonal and long-acting modern contraceptive methods. Women who reported no lifetime use of any method and, therefore, were not asked about current use, were considered to not currently be using a method. Women who reported current use of a permanent, barrier, hormonal or long-acting method were coded as using a modern method; "natural" methods were excluded from our measure of modern contraceptive use.

-Independent variables. Exposure to Oportunidades was measured in the 2006 wave with the question "Are you or anyone in the household currently a beneficiary of Oportunidades?" We included three education variables. A measure of respondents' educational attainment was created with three categories: primary school or lower, secondary school (equivalent to eighth grade in the United States) and greater than secondary. However, many women in our young sample may not have completed their education, so we also measured whether respondents were currently attending school. A third variable measured the educational attainment of the head of household (primary school or lower, secondary school, high school, greater than high school), which has been found to be associated with female fertility. ${ }^{34}$

Other independent variables included a binary variable measuring whether respondents had ever been married or in a cohabiting union; marriage is a proximate determinant of fertility ${ }^{35}$ and is used as a proxy for sexual activity. We measured indigenous ethnicity by respondents' reported ability to speak an indigenous language; another variable measured whether the head of household spoke an indigenous language, which is the Mexican government's preferred definition of indigenous status. ${ }^{51}$ Dichotomous variables measured whether respondents had access to other health insurance-such as Seguro Popular, the health insurance program for the poor introduced in 2002-or had been exposed to any social program other than Oportunidades-such as nutritional support for the elderly. Household composition could affect fertility decisions ${ }^{11}$ and is used to determine Oportunidades qualification and the amount of cash transfers; thus, we included the number of female household members aged 15-49 as a proxy for the household fertility potential. We also included measures of the total household size and the number of members older than 60 , but these variables were nonsignificant in analyses and did not alter our estimates of other relationships.

Finally, we constructed a wealth index using factor analysis $^{52}$ and household-level data from the full 2006 sample on five household characteristics (e.g., water source, electricity) and 12 property items (e.g., radio, TV, refrigerator). We divided the index into deciles, then collapsed the deciles into three categories ( 1 and 2, 3 and 4, and 5 and above) to capture variation in our rural, poor sample. We 
TABLE 1. Selected characteristics of rural Mexican women aged 15-24, by age-group and survey year, 1992-2009

\begin{tabular}{|c|c|c|c|c|c|c|c|c|c|}
\hline \multirow[t]{2}{*}{ Characteristic } & \multicolumn{3}{|l|}{1992} & \multicolumn{3}{|l|}{2006} & \multicolumn{3}{|l|}{2009} \\
\hline & $\begin{array}{l}\text { All } \\
(\mathrm{N}=11,138)\end{array}$ & $\begin{array}{l}15-19 \\
(\mathrm{~N}=6,460)\end{array}$ & $\begin{array}{l}20-24 \\
(N=4,678)\end{array}$ & $\begin{array}{l}\text { All } \\
(\mathrm{N}=3,832)\end{array}$ & $\begin{array}{l}15-19 \\
(\mathrm{~N}=2,199)\end{array}$ & $\begin{array}{l}20-24 \\
(\mathrm{~N}=1,633)\end{array}$ & $\begin{array}{l}\text { All } \\
(\mathrm{N}=6,363)\end{array}$ & $\begin{array}{l}15-19 \\
(N=3,648)\end{array}$ & $\begin{array}{l}20-24 \\
(\mathrm{~N}=2,715)\end{array}$ \\
\hline \multicolumn{10}{|l|}{ Educational attainment } \\
\hline None/primary & 66.5 & 65.1 & 68.5 & 29.2 & 22.7 & 38.0 & 22.8 & 18.8 & 28.2 \\
\hline Secondary & 28.0 & 29.3 & 26.2 & 42.3 & 48.3 & 34.1 & 46.2 & 51.0 & 39.9 \\
\hline >secondary & 5.4 & 5.5 & 5.3 & 28.5 & 29.0 & 27.9 & 30.8 & 30.0 & 31.9 \\
\hline Ever-married/cohabited & 38.5 & 21.0 & 62.7 & 32.4 & 15.6 & 55.1 & 35.5 & 19.6 & 56.7 \\
\hline Speaks an indigenous language & u & u & $\mathrm{u}$ & 10.8 & 11.0 & 10.4 & 12.3 & 13.0 & 11.3 \\
\hline Has access to other health insurance & $\mathrm{u}$ & $\mathrm{u}$ & $\mathrm{u}$ & 39.6 & 40.2 & 38.8 & 58.2 & 60.3 & 55.4 \\
\hline Household exposure to Oportunidades & $\mathrm{u}$ & $\mathrm{u}$ & $\mathrm{u}$ & 49.4 & 56.8 & 39.6 & $\mathrm{u}$ & u & u \\
\hline Ever/currently pregnant & 36.1 & 18.1 & 60.9 & 32.5 & 16.3 & 54.3 & 35.7 & 18.5 & 58.8 \\
\hline Currently using any contraceptive method & 13.2 & 5.1 & 24.4 & 15.8 & 6.1 & 28.8 & 18.9 & 9.4 & 31.8 \\
\hline Mean age at first birth & $18.1(2.2)$ & $16.8(1.3)$ & $18.6(2.2)$ & $18.3(2.3)$ & $16.9(1.4)$ & $18.7(2.3)$ & $18.0(2.2)$ & $16.5(1.2)$ & $18.5(2.2)$ \\
\hline Mean number of live births & $1.8(1.1)$ & $1.2(0.7)$ & $2.0(1.1)$ & $1.4(0.9)$ & $0.86(0.6)$ & $1.6(0.9)$ & $1.3(0.9)$ & $0.83(0.6)$ & $1.5(0.9)$ \\
\hline
\end{tabular}

Notes: $\mathrm{u}=$ unavailable. All data are percentages, unless otherwise noted. For means, figures in parentheses are standard deviations.

collapsed the Mexican states into six regions organized by state wealth; ${ }^{43}$ we dropped the richest region, which included only Mexico City, because Oportunidades was very poorly represented there in 2006.

\section{Analytical Approach}

We restricted data from each wave to women aged 15-24, separated by rural residence (areas with fewer than 2,500 inhabitants) or large urban residence (areas with 100,000 or more inhabitants). We split the samples into adolescents (15-19) and young adult women (20-24). Descriptive analyses included proportions and means to characterize trends in education, pregnancy and contraceptive use in each age-group, by rural or large urban residence. Multivariable analyses focused on rural women only.

Before conducting the multivariable analysis, we used the coarsened exact matching technique ${ }^{53,54}$ with 2006 data to balance key covariates among women exposed

FIGURE 1. Proportion of Mexican women aged 15-24, by educational attainment, according to urban-rural residence and survey year

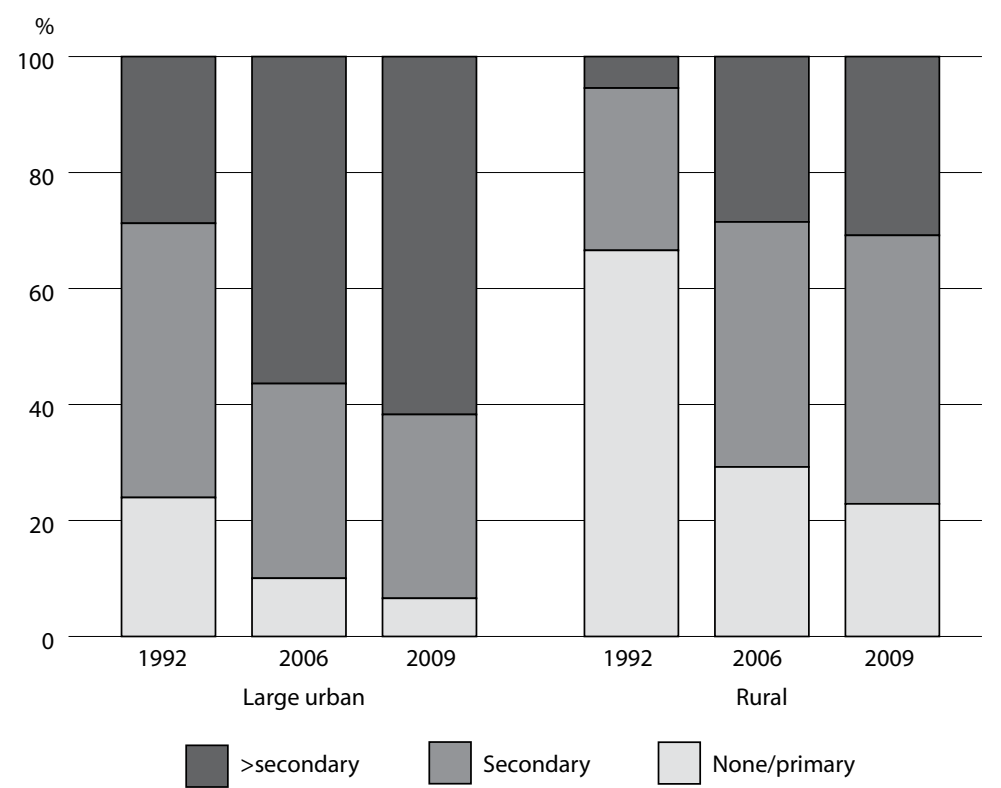

and not exposed to Oportunidades, so that the distributions of covariates were as similar as possible. Matching can improve causal inference in observational studies by reducing model dependence. ${ }^{53}$ Coarsened exact matching does not require specifying a model, in contrast to propensity score matching, which relies on correct specification of the matching model, and in which the closest match can actually be far away on individual covariates of interest. We selected variables for matching by examining covariate imbalance in the full sample and considering inclusion criteria for the Oportunidades program. We aimed to achieve a sample that retained as many exposed observations as possible, while also improving balance. We matched samples by age, educational attainment, current school status, head of household's educational attainment, marital status, indigenous ethnicity, exposure to social programs other than Oportunidades, number of women aged 15-49 in the household and wealth index. The L1 multivariate distance-an indicator of the overlap of the samples' variable distributions, for which 1 indicates no overlap and 0 complete overlap ${ }^{55}$-improved with matching, from 0.99 to 0.73 . Ninety-six percent of the sample matched, and only $2 \%$ of exposed observations did not match, which minimizes the potential for introducing bias. The final analytic sample consisted of 3,654 rural women aged 15-24.

We conducted multivariable logistic analyses with the matched sample to identify associations between exposure to Oportunidades and pregnancy experience and current modern contraceptive use, controlling for education and other covariates. For our analysis of pregnancy, we further restricted the sample to adolescents, to exclude pregnancies that could have occurred to women prior to inclusion in the Oportunidades program. We included a measure of current school attendance in this model, because many adolescents have not completed their education. For our analysis of contraceptive use, we used data from adolescent and young adult women, and included the measure of educational attainment. We transformed odds ratios from both models into predicted probabilities using Clarify, ${ }^{56}$ to ease interpretation of absolute and relative impacts. ${ }^{57}$ 


\section{FIGURE 2. Among Mexican women aged 15-24, trends in the proportion reporting current or past pregnancy and ever-use of modern contraceptives, by age-group and urban-rural residence, 1992-2009}
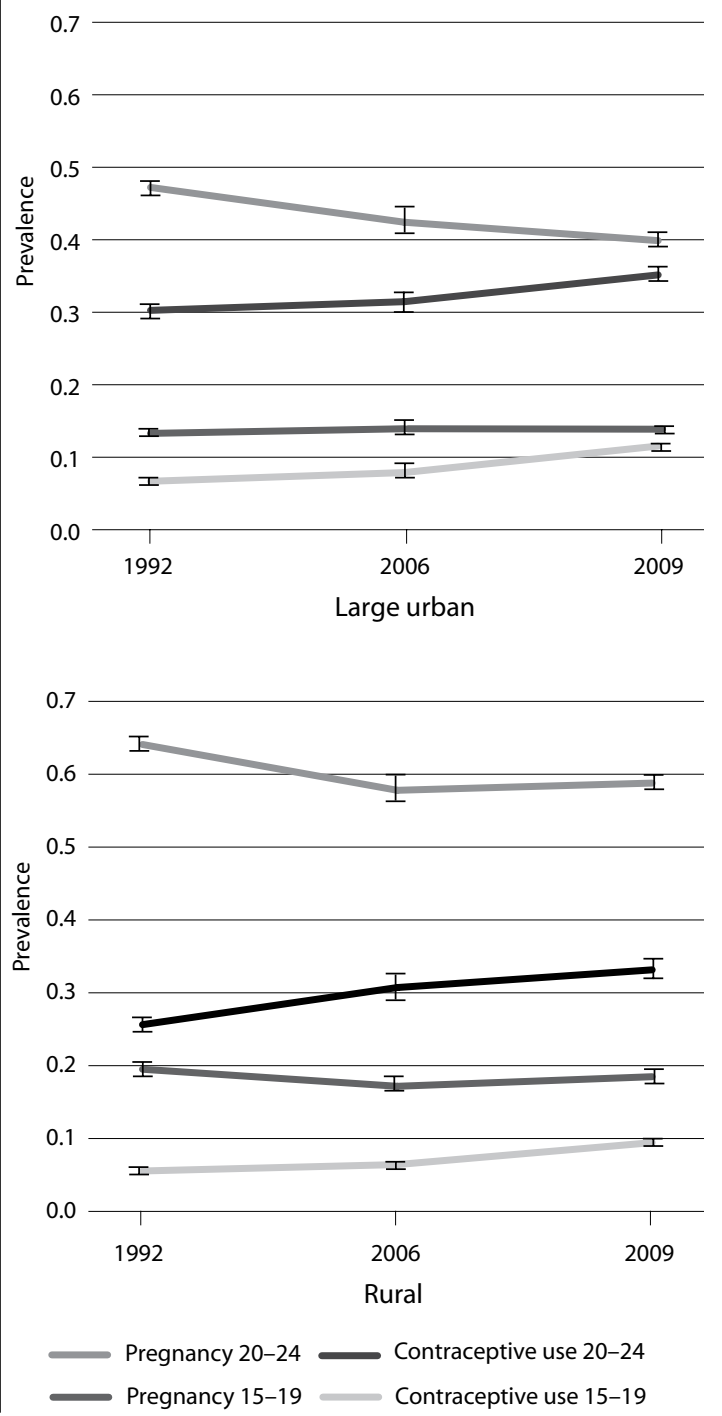

We performed five sensitivity analyses, including estimates with region as a fixed and as a random effect; an interaction between Oportunidades and educational attainment; an indicator of head of household or wife of head of household status (vs. child or other relation to the head of household); and wealth index decile categories; as well as one replacing individual-level indigenous language ability with head of household indigenous language ability. Our models were robust to these sensitivity analyses; we present only the main models below. To further explore the relationship of Oportunidades, school attendance and adolescent pregnancy, we also used a structural equation model ${ }^{58}$ to estimate indirect effects of Oportunidades on pregnancy mediated by schooling, and found that our results were robust to the choice of model, indicating stable models and increasing our confidence in the estimates. All analyses were conducted using Stata version 12.

\section{RESULTS}

The educational attainment among rural women aged 15-24 appears to have increased substantially over the three survey waves: The proportions of women in 1992, 2006 and 2009 who reported only a secondary education were $28 \%, 42 \%$ and $46 \%$, respectively, and the proportions who reported more than a secondary education were 5\%, 29\% and 31\% (Table 1). Thirty-six percent of women in 1992 reported having ever been pregnant; that proportion was 33\% in 2006, but returned to 36\% in 2009. Current use of any contraceptive method (including sterilization and natural methods) increased somewhat over time (from 13\% in 1992 to $16 \%$ in 2006 and 19\% in 2009), although overall use remained low. It is worth noting, however, that contraceptive prevalence is not the same across age-groups: For example, in 2006, 6\% of adolescents reported currently practicing contraception, whereas $29 \%$ of young adults did so (not shown).

Changes in educational attainment among young rural women occur in a context of persistent disparities in education compared with young women residing in large urban areas, which can be seen at each time point (Figure 1). We also see rural-urban differences in the proportions of women who had ever experienced a pregnancy, especially among women aged 20-24, but not in the proportions of women currently using contraceptives (Figure 2). In sum, disparities in adolescent pregnancy and education between rural and urban adolescent women are large and persist over time, while disparities in contraceptive use are smaller. While education levels have increased dramatically among rural and urban young women, pregnancy and

\begin{tabular}{|c|c|c|c|c|}
\hline \multirow[t]{2}{*}{ Characteristic } & \multicolumn{2}{|l|}{ Exposed } & \multicolumn{2}{|l|}{ Not exposed } \\
\hline & $\begin{array}{l}15-19 \\
(\mathrm{~N}=1,232)\end{array}$ & $\begin{array}{l}20-24 \\
(\mathrm{~N}=629)\end{array}$ & $\begin{array}{l}15-19 \\
(\mathrm{~N}=914)\end{array}$ & $\begin{array}{l}20-24 \\
(\mathrm{~N}=879)\end{array}$ \\
\hline \multicolumn{5}{|l|}{ Educational attainment } \\
\hline None/primary & 21.2 & 46.0 & $25.5^{* * *}$ & $36.4^{* *}$ \\
\hline Secondary & 53.3 & 31.3 & 41.6 & 37.9 \\
\hline >secondary & 25.6 & 22.7 & 32.9 & 25.7 \\
\hline Currently in school & 47.7 & 9.9 & $43.1^{* * *}$ & 10.7 \\
\hline Ever-married/cohabited & 11.4 & 49.9 & $20.9^{* * *}$ & $60.3^{* * *}$ \\
\hline Speaks an indigenous language & 15.3 & 17.3 & $5.7^{* * *}$ & $6.6^{* * *}$ \\
\hline Child of head of household & 83.1 & 59.5 & $70.5^{* * *}$ & $42.3^{* * *}$ \\
\hline Has access to other health insurance & 41.1 & 38.3 & 38.2 & 37.0 \\
\hline Exposed to other social program & 47.2 & 49.6 & $22.4^{* * *}$ & $25.7^{* * *}$ \\
\hline Mean household size & $6.6(2.55)$ & $6.4(2.76)$ & $5.5(2.3)^{* * *}$ & $5.2(2.6)^{* * *}$ \\
\hline $\begin{array}{l}\text { Mean no. of women 15-49 in household } \\
\text { Wealth index }\end{array}$ & \multicolumn{3}{|c|}{ Wealth index } & $1.7(0.98)^{* * *}$ \\
\hline $1-2$ & 58.0 & 57.4 & $27.9^{* * *}$ & $29.6^{* * *}$ \\
\hline $3-4$ & 23.9 & 27.5 & 24.3 & 29.2 \\
\hline $5-10$ & 18.1 & 15.1 & 47.8 & 41.2 \\
\hline Ever/currently pregnant & 12.3 & 50.9 & $21.2^{* * *}$ & $58.3^{*}$ \\
\hline $\begin{array}{l}\text { Currently using a modern } \\
\text { contraceptive method }\end{array}$ & 3.8 & 20.4 & $7.9^{* * *}$ & $26.9^{* *}$ \\
\hline Mean age at first birth $\dagger$ & $16.8(1.4)$ & $18.5(2.4)$ & $16.9(1.4)$ & $18.8(2.2)^{*}$ \\
\hline
\end{tabular}

*Different from same-aged women in exposed group at $\mathrm{p}<.05$. **Different from same-aged women in exposed group at $p<.01$. ${ }^{* * *}$ Different from same-aged women in exposed group at $p<.001$. Among 632 respondents who had given birth. Notes: All data are percentages, unless otherwise noted. For means, figures in parentheses are standard deviations. $P$ values from $t$ test for continuous variables, pr test for binary variables or chi-square for categorical variables. Data for pregnancy and contraceptive use outcomes are missing for 202 women. 
contraceptive use have remained fairly flat.

In the matched sample, compared with women not exposed to Oportunidades, those who had been exposed to the program differed by most of the measures studied (Table 2, page 209). For example, the proportion of adolescents with a primary school education or less in 2006 was smaller among women exposed to the program than among those not exposed ( $21 \%$ vs. $26 \%$ ), while the proportion of young women with that level of education was larger among exposed women (46\% vs. 36\%); a greater proportion of adolescents exposed to the program reported currently being in school (48\% vs. 43\%). In addition, smaller proportions of adolescent and young adult women exposed to Oportunidades had experienced a pregnancy ( $12 \%$ vs. $21 \%$, and $51 \%$ vs. $58 \%$ ) or reported current use of a modern contraceptive method ( $4 \%$ vs. $8 \%$, and $20 \%$ vs. $27 \%$ ).

In multivariable analyses among the matched sample of women aged 15-19, exposure to Oportunidades was not independently associated with pregnancy experience after education and other variables were controlled for (Table 3). Adolescents who reported ever being married or hav-

TABLE 3. Odds ratios (and 95\% confidence intervals) from regression analyses identifying associations between exposure to Oportunidades and pregnancy among women aged 15-19, 2006

Characteristic

Exposure to Oportunidades

Yes

No (ref)

Currently in school

Yes

No (ref)

Age

$15-16$

$17-19$ (ref)

Ever-married/cohabited

Yes

No (ref)

Speaks an indigenous language

Yes

No (ref)

No. of women aged 15-49 in

household

Odds ratio

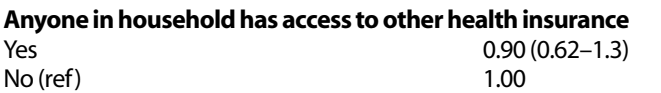

Anyone in household exposed to other social program

Yes

No (ref)

$1.20(0.83-1.70)$

1.00

Head of household educational attainment

None (ref)

1.00

Primary

Secondary

>secondary

$1.00(0.67-1.51)$

$1.35(0.71-2.57)$

$0.42(0.12-1.52)$

Total household size

$1.95(0.97-1.13)$

Notes: $r e f=$ reference group. Sample size $=2,034$.

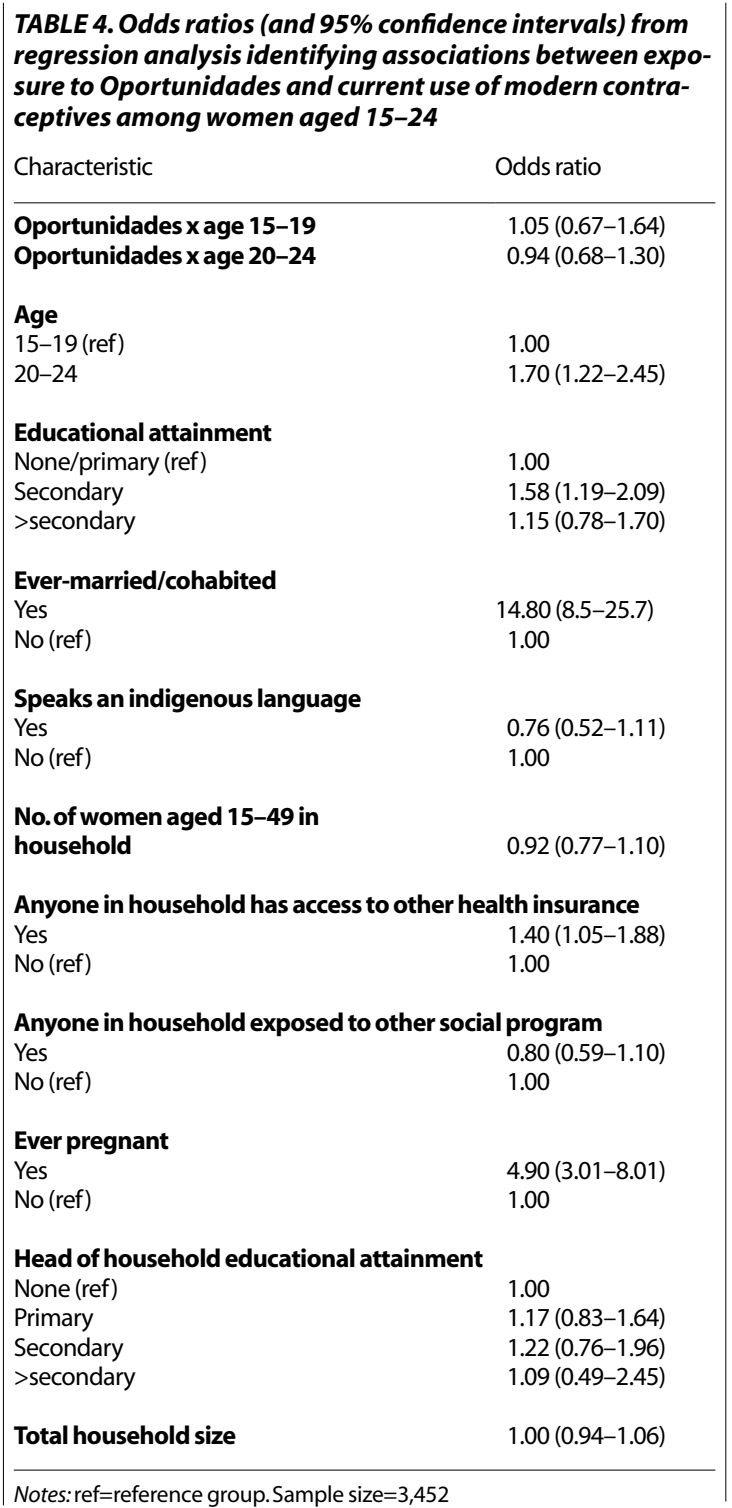

ing cohabited were substantially more likely to have been pregnant (odds ratio, 48.8); current school attendance, younger age and greater number of reproductive-age women in the household were negatively associated with pregnancy experience (0.4-0.7).

We calculated predicted probabilities for key variables of Oportunidades exposure and schooling (not shown). Among adolescents currently in school, those exposed to Oportunidades had a $5 \%$ predicted probability of pregnancy (confidence intervals, 0.04-0.08), when all other covariates were held at the mean, whereas nonexposed adolescents had a 7\% probability (0.05-0.10). Among adolescents not in school, the probability of pregnancy was about double for each group: 10\% (0.07-0.12) and 13\% (0.10-0.16), respectively. In models stratified by marital status, ever-married adolescents exposed to Oportunidades had a $67 \%$ probability of pregnancy (0.58-0.75), and ever-married adolescents not exposed to the program had a $73 \%$ probability (0.66-0.79); the difference between 
groups was not significant. The structural equation model confirmed the strong, direct negative association between being in school and pregnancy, and also supported the findings from the predicted probabilities. Oportunidades had a small, indirect, negative effect on pregnancy through current school attendance ( $\mathrm{p}=.05$ ); 9\% of the program's total effect was mediated by school attendance.

In multivariable analyses among the matched samples of women aged 15-24, exposure to Oportunidades was not independently associated with current use of modern contraceptives among adolescents or young adult women (Table 4). The interaction terms included were nonsignificant, and thus Oportunidades appears not to moderate the relationship of age and contraceptive use. Having a secondary education (compared with a primary education or lower), having ever been married and having other health insurance were positively associated with contraceptive use (odds ratios, 1.4-14.8).

In models stratified by marital status, having health insurance was not independently associated with contraceptive use among unmarried women, but previous pregnancy had an even stronger association among unmarried women than among married women (not shown). Oportunidades and health insurance together resulted in a significantly higher probability of modern contraceptive use among married women (41\%) than among married women without Oportunidades or health insurance (34\%). Speaking an indigenous language was not independently associated with either outcome.

\section{DISCUSSION}

It is important to evaluate large-scale social policies like Oportunidades rigorously and thoroughly, and on an ongoing basis. Mexico invests 100 million pesos per year (about $\$ 8$ million) ${ }^{29}$ in the program, yet assessment has been hindered by a lack of population-based longitudinal data with the necessary information on program exposure. For our analysis, we used the most recent populationbased data set to assess the program, and found that Oportunidades had no direct effect on adolescent pregnancy in a national context of increasing rates of schooling and little to no change in adolescent pregnancy rates. This suggests that schooling alone may not be enough to have an impact on adolescent fertility, and that policy and programmatic efforts need to focus on other components of the Oportunidades program-such as health service delivery-to improve adolescent and young women's reproductive health behaviors and outcomes. Our findings of persistently low contraceptive use by adolescent and young rural women suggest that increasing access to contraceptive servicesone strategy to delay early fertility-needs to be expanded to nulliparous women beyond the context of antenatal care. Our results further indicate that access to health insurance plays a role in contraceptive use. Oportunidades enrollment may facilitate enrollment in Seguro Popular; future research using newer data sources from the Seguro Popular program may allow for study of contraceptive use among women covered by Seguro Popular.

We sought to capture the effects of Oportunidades on young women's reproductive behaviors, beyond any that may have been mediated by education or other key covariates. We found no evidence that Oportunidades had a direct effect on pregnancy among adolescents or on current modern contraceptive use among adolescent and young adult women. In addition, the program did not increase pregnancy among young beneficiaries. School attendance partially mediated the effect of Oportunidades on lower odds of adolescent pregnancy. Our measures of education-current school attendance and educational attainment-were negatively associated with pregnancy and positively associated with contraceptive use, respectively.

We found a lower prevalence of contraceptive use in our matched sample than previously reported among Oportunidades beneficiaries of reproductive age, ${ }^{27}$ this is likely, in part, because of our younger sample. Contraceptive use was comparable among rural and urban women aged 1524 in the 2009 data, suggesting low rates of contraceptive use among young women persist, regardless of location or Oportunidades exposure. Contraceptive use increased between 1998 and 2007 among married Oportunidades beneficiaries aged 15-19 with at least one child. ${ }^{27}$ We found that marriage or cohabitation and pregnancy experience were strong correlates of modern contraceptive use, but did not find evidence of a direct impact of Oportunidades.

Oportunidades stipulates that adolescents and adults in beneficiary households obtain biannual check-ups and other health services, which could be expected to have direct effects on pregnancy and contraceptive use. Women in our sample may not have received check-ups, however, because cash payments are not conditional on obtaining them. Alternatively, women may have received check-ups, but the visits may not have addressed reproductive health and contraception, because Oportunidades does not dictate the content of counseling. Finally, women may have received appropriate reproductive health counseling during check-ups, but improved access to health care and better information had no effect on their behavior.

Health insurance was associated with contraceptive use in this population of rural women. Our measure of health insurance may have been a proxy for access to and supply of services, including family planning. Oportunidades provides family planning services in the context of antenatal or postpartum care. ${ }^{59}$ In our rural matched sample, marriage and pregnancy experience were associated with contraceptive use, consistent with this scenario. Among unmarried young women in our sample, health insurance was not associated with contraceptive use, but pregnancy experience was, further highlighting the role of fertility in uptake of contraceptive services. Supply of services or a proxy of supply has been positively correlated with contraceptive use among the poor worldwide, and Latin America has larger wealth disparities in contraceptive use than SubSaharan Africa or South and Southeast Asia. ${ }^{60}$ Supply and access-via health insurance-may be the key to increasing 
contraceptive use in this young, poor population. If use of health services is to increase, services should be accessible, of good quality and targeted to poor young women.

Education levels improved markedly among rural women aged 15-24 between 1992 and 2009, and contraceptive use increased slowly but steadily. However, no consistent decline in pregnancy experience was seen in our descriptive analyses, although a strong negative correlation between school attendance and pregnancy was found in our multivariate analyses. These results suggest that being in school, rather than having a certain level of education, delays pregnancy. This raises questions about potential community-level education effects and the importance of content or quality of education received by beneficiaries, in addition to school attendance in itself. ${ }^{32,36,38}$

\section{Strengths and Limitations}

Our results should be interpreted with the following limitations in mind. We were able to assess exposure to Oportunidades at only one time point (2006), because other data sets did not contain an program exposure variable or had too much missing data on reproductive outcomes. Because some of our results were based on small subsamples of women, we may not have had sufficient power to detect true differences. Although the ENADID is a high-quality, population-based survey, it may have sampled a nonrepresentative group of Oportunidades beneficiaries, which would limit the generalizability of our results to the larger population of young rural program beneficiaries. We used a self-reported measure of Oportunidades exposure, and data were not available on length of program exposure; previous research among beneficiaries reported mixed results by length of exposure. ${ }^{27,48}$ Women in our sample were asked about current exposure, so our measure may not have captured those who had been exposed, but left the program. We restricted our pregnancy models to women aged 15-19 to avoid including any pregnancies that could have occurred prior to program inclusion in 1998 or 2000. Our variables of interest were self-reported, so if there was systematic variation in responses by exposure to Oportunidades, it would introduce bias; however, the population-based data we used is likely less biased than the program data used by previous analyses, which may suffer from social desirability bias. Finally, we inferred causal relationships from an observational study. This analysis is subject to the limitations of all observational studies, such as potential omitted variables bias; however we used a matched sample to reduce model dependence and performed sensitivity analyses to assess the robustness of our results.

\section{Conclusions}

Oportunidades appears to have no direct effect on rural adolescent pregnancy and young women's current modern contraceptive use. Education was positively associated with contraceptive use and negatively associated with pregnancy among adolescents. Through its effect on edu- cation, Oportunidades indirectly influences fertility among adolescents. The overall level of contraceptive use remains low among young women in Mexico, especially among adolescents. It is important for Mexico to focus on strategies to increase contraceptive use among young rural nulliparous women, regardless of whether they are enrolled in Oportunidades.

\section{REFERENCES}

1. Feldman BS et al., Contraceptive use, birth spacing, and autonomy: an analysis of the Oportunidades program in rural Mexico, Studies in Family Planning, 2009, 40(1):51-62.

2. Potter JE, The persistence of outmoded contraceptive regimes: the cases of Mexico and Brazil, Population and Development Review, 1999 25(4):703-739.

3. Loewenberg S, The plight of Mexico's indigenous women, Lancet, 2010, 375(9727):1680-1682

4. Flórez Nieto CE and Nunez J, Teenage childbearing in Latin American countries, 2001, New York: Inter-American Development Bank, <http://www.iadb.org/res/publications/pubfiles/pubR-434. pdf>, accessed June 2, 2010

5. Cleland J et al., Family planning: the unfinished agenda, Lancet, 2006, 368(9549):1810-1827.

6. World Health Organization, WHO Guidelines on Preventing Early Pregnancy and Poor Reproductive Health Outcomes Among Adolescents in Developing Countries, 2011, <http://whqlibdoc.who.int publications/2011/9789241502214 eng.pdf>, accessed June 1, 2012.

7. United Nations Population Fund, Reducing Poverty and Achieving the Millennium Development Goals: Arguments for Investing in Reproductive Health and Rights, 2005, <http://www.unfpa.org/webdav/site/ global/shared/documents/publications/2005/reducingpoverty_ mdg.pdf>, accessed June 1, 2012.

8. Lagarde M, Haines A and Palmer N, Conditional cash transfers for improving uptake of health interventions in low- and middleincome countries: a systematic review, Journal of the American Medical Association, 2007, 298(16):1900-1910.

9. Fiszbein A et al., Conditional Cash Transfers, Reducing Present and Future Poverty, Washington, DC: World Bank, 2009, $<\mathrm{http}: / /$ siteresources.worldbank.org/INTCCT/Resources/ 5757608-1234228266004/PRR-CCT_web_noembargo.pdf>, accessed Apr. 22, 2013.

10. Fernald LC, Gertler PJ and Neufeld LM, 10-year effect of Oportunidades, Mexico's conditional cash transfer programme, on child growth, cognition, language, and behaviour: a longitudinal follow-up study, Lancet, 2009, 374(9706):1997-2005.

11. Stecklov $\mathrm{G}$ et al., Unintended effects of poverty programmes on childbearing in less developed countries: experimental evidence from Latin America, Population Studies, 2007, 61(2):125-140.

12. Fernald LCH and Hidrobo M, Effect of Ecuador's cash transfer program (Bono de Desarrollo Humano) on child development in infants and toddlers: a randomized effectiveness trial, Social Science \& Medicine, 2011, 72(9):1437-1446.

13. Baird SJ et al., Effect of a cash transfer programme for schooling on prevalence of HIV and herpes simplex type 2 in Malawi: a cluster randomised trial, Lancet, 2012, 379(9823):1320-1329.

14. Lim SS et al., India's Janani Suraksha Yojana, a conditional cash transfer programme to increase births in health facilities: an impact evaluation, Lancet, 2010, 375(9730):2009-2023.

15. Bosman J, City will stop paying the poor for good behavior, New York Times, Mar. 31, 2010, p. Al.

16. Riccio J et al., Towards Reduced Poverty Across Generations. Early Findings from New York City's Conditional Cash Transfer Program 2010, New York: MDRC, <http://www.mdrc.org/sites/default/files/ Toward\%20Reduced $\% 20$ Poverty $\% 20$ Across $\% 20$ Generations $\% 20$ ES.pdf>, accessed July 21, 2010. 
17. Gaarder MM, Glassman A and Todd JE, Conditional cash transfers and health: unpacking the causal chain, Journal of Development Effectiveness, 2010, 2(1):6-50.

18. Lagarde M, Haines A and Palmer N, The impact of conditional cash transfers on health outcomes and use of health services in low and middle income countries, Cochrane Database of Systematic Reviews, 2009, Issue 4, No. CD008137.

19. Ranganathan $M$ and Lagarde $M$, Promoting healthy behaviours and improving health outcomes in low and middle income countries: a review of the impact of conditional cash transfer programmes, Preventive Medicine, 2012, 55(Suppl.):S95-S105.

20. Robertson L et al., Effects of unconditional and conditional cash transfers on child health and development in Zimbabwe: a clusterrandomised trial, Lancet, 2013, 381(9874):1283-1292.

21. Gilmour S, Hamakawa $\mathrm{T}$ and Shibuya K, Cash-transfer programmes in developing countries, Lancet, 2013, 381(9874):12541255.

22. Fernald LC, Gertler PJ and Neufeld LM, Role of cash in conditional cash transfer programmes for child health, growth, and development: an analysis of Mexico's Oportunidades, Lancet, 2008, 371(9615):828-837.

23. Rivera JA et al., Impact of the Mexican program for education, health, and nutrition (Progresa) on rates of growth and anemia in infants and young children: a randomized effectiveness study, Journal of the American Medical Association, 2004, 291(21):2563-2570.

24. Behrman JR et al., Long-term effects of Oportunidades on rural infant and toddler development, education and nutrition after almost a decade of exposure to the program, in: External Evaluation of Oportunidades 2008, 1997-2007: Ten Years of Intervention in Rural Areas (1997-2007), Vol. I, Mexico City: Secretaria de Desarollo Social (SEDESOL), 2009, <http://www.oportunidades.gob.mx/ EVALUACION/es/wersd53465sdgl/docs/2008/2008_volume_i. pdf $>$, accessed Oct. 25, 2013.

25. Gertler P, The Impact of PROGRESA on Health, Washington, DC: International Food Policy Research Institute, 2000.

26. Skoufias E, Davis B and de la Vega S, Targeting the poor in Mexico: an evaluation of the selection of households for PROGRESA, Discussion Paper Briefs, Washington, DC: International Food Policy Research Institute (IFPRI), 1999, <http://www.ifpri.org/publication/ targeting-poor-mexico-1>, accessed June 2, 2010.

27. Bautista Arredondo $S$ et al., Ten years of Oportunidades in rural areas: Effects on health services utilization and health status, in: External Evaluation of Oportunidades 2008, 1997-2007: Ten Years of Intervention in Rural Areas (1997-2007), Vol. II, Mexico City: SEDESOL, 2009, <http://www.oportunidades.gob.mx/ EVALUACION/es/wersd53465sdgl/docs/2008/2008_volume_ ii.pdf>, accessed Oct. 28, 2013.

28. SEDESOL, Oportunidades atiende a 5.8 millones de familias en el país, 2012, <http://www.oportunidades.gob.mx/Portal/wb/ Web/oportunidades_atiende_a_58_millones_de_familias_>, accessed Apr. 20, 2013.

29. SEDESOL, Oportunidades, 15 Years of Results, Mexico City: SEDESOL, 2012

30. Skoufias E, PROGRESA and its impact on the welfare of rural households in Mexico, Washington, DC: IFPRI, 2005, No. 139, $<$ http://www.ifpri.org/publication/progresa-and-its-impacts-welfarerural-households-mexico>, accessed Feb 2, 2010.

31. Bongaarts J, Completing the fertility transition in the developing world: the role of educational differences and fertility preferences, Population Studies, 2003, 57(3):321-335.

32. Castro Martín T, Women's education and fertility: results from 26 Demographic and Health Surveys, Studies in Family Planning, 1995, 26(4): 187-202.

33. Hirschman C, Why fertility changes, Annual Review of Sociology, 1994, 20(1):203-233.

34. Jejeebhoy SJ, Women's Education, Autonomy, and Reproductive Behavior: Experience from Developing Countries, Oxford, UK:
Clarendon Press, 1995.

35. Bongaarts J, A framework for analyzing the proximate determinants of fertility, Population and Development Review, 1978, 4(1):105132

36. Caldwell JC, Mass education as a determinant of the timing of fertility decline, Population and Development Review, 1980, 6(2):225255.

37. DeRose LF and Kravdal O, Educational reversals and firstbirth timing in sub-Saharan Africa: a dynamic multilevel approach, Demography, 2007, 44(1):59-77.

38. Kravdal $\varnothing$, Education and fertility in sub-Saharan Africa: individual and community effects, Demography, 2002, 39(2):233-250.

39. Larsen U and Hollos M, Women's empowerment and fertility decline among the Pare of Kilimanjaro region, Northern Tanzania, Social Science \& Medicine, 2003, 57(6):1099-1115.

40. Cleland J, Education and Future Fertility Trends, with Special Reference to Mid-Transition Countries, New York: United Nations, 2002

41. Parker $S$ and Behrman JR, Following young adults who benefited from Oportunidades for nearly a decade: impact of the program on rural education and achievement, in: External Evaluation of Oportunidades 2008, 1997-2007: Ten Years of Intervention in Rural Areas (1997-2007), Vol. I, Mexico City: SEDESOL, 2009, <http:// www.oportunidades.gob.mx/EVALUACION/es/wersd53465sdgl/ docs/2008/2008_volume_i.pdf>, accessed Oct. 25, 2013.

42. Mancera Corcuera C and Serna Hernandez L, A PS, Learning gaps among Oportunidades scholarship recipients in primary and junior high school: association with education modality and multigrade organization, in: External Evaluation of Oportunidades 2008, 1997-2007: Ten Years of Intervention in Rural Areas (1997-2007), Vol. III, Mexico City: SEDESOL, 2009, <http://www.oportunidades.gob. mx/EVALUACION/es/wersd53465sdgl/docs/2008/2008_tomo_ iii_calidad_servicios_educacion.pdf>, accessed Oct. 28, 2013.

43. Juarez F et al., Las Necesidades de Salud Sexual y Reproductiva de las Adolescentes en Mexico: Retos y Oportunidades, New York: Guttmacher Institute, 2010

44. Barber SL and Gertler PJ, Empowering women to obtain high quality care: evidence from an evaluation of Mexico's conditional cash transfer programme, Health Policy and Planning, 2009, 24(1):18-25

45. Sosa-Rubí SG et al., Learning effect of a conditional cash transfer programme on poor rural women's selection of delivery care in Mexico, Health Policy and Planning, 2011, 26(6):496-507.

46. Barber SL, Mexico's conditional cash transfer programme increases cesarean section rates among the rural poor, European Journal of Public Health, 2010, 20(4):383-388

47. Barber SL, Bertozzi SM and Gertler PJ, Variations in prenatal care quality for the rural poor in Mexico, Health Affairs, 2007 , 26(3):w310-w323.

48. Lamidrad-Figueroa $\mathrm{H}$ et al., Heterogeneous impact of the social programme Oportunidades on use of contraceptive methods by young adult women living in rural areas, Journal of Development Effectiveness., 2010, 2(1):74-86.

49. Barber SL, Family planning advice and postpartum contraceptive use among low-income women in Mexico, International Family Planning Perspectives, 2007, 33(1):6-12.

50. Instituto Nacional Nacional de Estadística y Geografía de México, Encuesta Nacional de la Dinamica Demografica, 2011, <http:// www.inegi.org.mx/est/contenidos/proyectos/encuestas/hogares/ especiales/enadid/default.aspx>, accessed Apr. 22, 2013.

51. Comision Nacional para el Desarrollo de los Pueblos Indigenas, Indicadores y estadísticas, 2012, <http://www.cdi.gob.mx/index. php?option=com_content\&view $=$ category\&id=38\&Itemid=54>, accessed June 1, 2012

52. DeVillis RF, Factor analysis strategies, in: DeVillis RF, ed., Scale Development. Theory and Applications, Newbury Park, CA, USA: Sage, 1991. 
53. Ho DE et al., Matching as nonparametric preprocessing for reducing model dependence in parametric causal inference, Political Analysis, 2007, 15(3):199-236

54. King $G$ et al., Comparative Effectiveness of Matching Methods for Causal Inference, Cambridge, MA, USA: Harvard University, 2011, <http://132.206.150.50/lib/exe/fetch.php/groups/dstephens/reading/king_ps_paradox.pdf>, accessed Oct. 28, 2013.

55. Iacus $S$, King $G$ and Porro $G$, Causal inference without balance checking: coarsened exact matching, Political Analysis, 2012, 20(1):1-24.

56. Tomz M, Wittenberg J and King G, CLARIFY, Software for interpreting and presenting statistical results, Journal of Statistical Software, 2003, 8(1):3-29.

57. King G, Tomz M and Wittenberg J, Making the most of statistical analyses: improving interpretation and presentation, American Journal of Political Science, 2000, 44(2):347-361.

58. Vanderweele TJ, Mediation analysis with multiple versions of the mediator, Epidemiology, 2012, 23(3):454-463.

59. Saunders M and Sharma S, Mobilizing Political Support and Resources for Family Planning in a Decentralized Setting: Guidelines for Latin American and Caribbean Countries, Washington, DC, United States Agency for International Development, 2008.

60. Gakidou E and Vayena E, Use of modern contraception by the poor is falling behind, PLoS Medicine, 2007, 4(2):e31

\section{RESUMEN}

Contexto: "Oportunidades" es un extenso programa de transferencias condicionadas de dinero en efectivo en México. Es importante examinar si el programa tiene algún efecto directo en la experiencia del embarazo y en el uso de anticonceptivos entre mujeres jóvenes del medio rural, además de sus efectos en la educación.

Métodos: Se usaron datos de las olas de 1992, 2006 y 2009 de una encuesta poblacional representativa a nivel nacional para describir las tendencias en la experiencia del embarazo, el uso de anticonceptivos y la educación en mujeres adolescentes (15-19) y jóvenes adultas (20-24) del medio rural en México. Para examinar las diferencias en la experiencia del embarazo y el uso actual de anticonceptivos modernos entre las mujeres jóvenes, se condujeron análisis de regresión logística multivariada en muestras pareadas de mujeres con y sin exposición al programa Oportunidades en el año 2006, se calcularon predicciones de probabilidad y se estimaron los efectos indirectos.

Resultados: A lo largo de las tres olas de la encuesta, la proporción de mujeres adolescentes y jóvenes adultas que reportaron haber estado embarazadas alguna vez permaneció estable (33-36\%) y el uso de anticonceptivos aumentó sostenidamente (del 13\% en 1992 al 19\% en 2009). Los niveles de educación mejoraron de forma espectacular. La proporción de mujeres con educación secundaria aumentó del 28\% en 1992 al 46\% en 2009. En los análisis multivariados, la exposición a Oportunidades no mostró ninguna asociación con la experiencia del embarazo entre las adolescentes. El nivel educativo, el estado conyugal, la experiencia del embarazo y el acceso a los seguros de salud-pero no la exposición a Oportunidades-influyeron positivamente en el uso de anticoncepción moderna entre las mujeres adolescentes y jóvenes adultas.

Conclusión: A través de su efecto en la educación, el progra- ma Oportunidades influye indirectamente en la fecundidad de las adolescentes. Es importante que México se concentre en estrategias para aumentar el uso de anticonceptivos entre las mujeres jóvenes nulíparas del medio rural, independientemente de que estén inscritas o no en Oportunidades.

\section{RÉSUMÉ}

Contexte: Oportunidades est un vaste programme de transfert conditionnel d'espèces au Mexique. Il importe d'examiner si le programme produit un effet direct sur l'expérience de la grossesse et la pratique contraceptive parmi les jeunes femmes des milieux ruraux, mis à part ceux obtenus par le biais de l'éducation.

Méthodes: Les données des vagues 1992, 2006 et 2009 d’une enquête en population nationalement représentative ont servi à décrire les tendances de l'expérience de la grossesse, de la pratique contraceptive et de l'éducation parmi les adolescentes (15 à 19 ans) et les jeunes femmes adultes (20 à 24 ans) du Mexique rural. Pour examiner les différences d'expérience de la grossesse et de pratique contraceptive moderne courante parmi les jeunes femmes, des analyses de régression logistique multivariées ont été effectuées sur des échantillons de 2006 appariés de femmes avec et sans exposition à Oportunidades, les probabilités prédites ont été calculées et les effets indirects ont été estimés.

Résultats: Sur les trois vagues de l'enquête, la proportion d'adolescentes et de jeunes femmes adultes déclarant avoir jamais été enceintes demeure égale (33-36\%) tandis que la pratique contraceptive augmente régulièrement (de 13\% en 1992 à 19\% en 2009). Le niveau de scolarité augmente de manière spectaculaire, la proportion de femmes dotées d'une éducation secondaire passant de 28\% en 1992 à 46\% en 2009. Dans les analyses multivariées, l'exposition à Oportunidades ne paraît pas associée à l'expérience de la grossesse parmi les adolescentes. Le niveau de scolarité, l'état matrimonial, l'expérience de la grossesse et l'accès à l'assurance santé - mais pas l'exposition à Oportunidades - sont associés positivement à la pratique contraceptive moderne parmi les adolescents et les jeunes femmes adultes.

Conclusion: Par son effet sur l'éducation, le programme Oportunidades influence indirectement la fécondité des adolescentes. Il importe que le Mexique se concentre sur des stratégies d'accroissement de la pratique contraceptive parmi les jeunes femmes nullipares des milieux ruraux, indépendamment de leur inscription à Oportunidades.

\section{Acknowledgments}

The research on which this article was based was supported by Society of Family Planning Student Award \#SFP5-2 and Agency for Health Care Research and Quality T32 Postdoctoral Award \#HS017582, Predoctoral Award \#HS013853, and Clinical and Translational Science Award \#NCRR025016. No funding source had any role in the design, writing or decision to publish this manuscript. The views and opinions expressed are those of the author or authors, and do not necessarily represent the views and opinions of Society of Family Planning or the National Institutes of Health.

Author contact: darneyb@ohsu.edu 